IRSH 48 (2003), pp. I-26 DOI: I0.10I7/S002085900200090I

(C) 2003 Internationaal Instituut voor Sociale Geschiedenis

\title{
Social Mobility from a Kinship Perspective: Rural Liaoning, I789-1909*
}

\author{
CAMERON CAMPBElland JAmes LEE
}

Summary: This paper examines the role of kin networks in intergenerational mobility in rural Liaoning, China, I789-1909. Classic studies of social mobility in historical China based on the records of imperial examination candidates suggest that society was relatively fluid. It has been claimed, however, that associations between fathers'and sons' outcomes overestimate the fluidity of historical Chinese society because many men who achieved prominence had been helped by senior kin other than their fathers. We test these claims by applying event-history techniques to longitudinal, nominative household register data, measuring the effects of characteristics of kin on the chances of obtaining an official title. Even though distant kin influenced the chances of obtaining a title, kin networks did not monopolize opportunities. There was substantial downward mobility among the sons of prominent families, and high proportions of titleholders were new, in the sense of not having any senior kin who held titles.

\section{INTRODUCTION}

A central question in the study of Chinese society before the twentieth century has been whether it was open or closed, that is, how much social mobility there was between one generation and the next. Most of the debate and associated empirical work have focused on elites. On the one hand, it has been argued that the merit-based imperial examination system offered opportunities for advancement to those who were not the sons or grandsons of officials. Society, as a result, was relatively "open". ${ }^{\text {I On the }}$ other hand, it has been claimed that examination candidates whose fathers and grandfathers were undistinguished often had more distant kin who

\footnotetext{
* An earlier version of this paper was presented at the HSN Workshop on Large Databases: Results and Best Practices, Amsterdam, the Netherlands, 17-18 May 200I. We are grateful to participants and to an anonymous referee for their comments. While working on this paper, Campbell was supported by a grant from the UCLA Academic Senate Council on Research. I. Ping-ti Ho, The Ladder of Success in Imperial China: Aspects of Social Mobility (1368-19II) (New York, 1962), pp. I-52.
} 


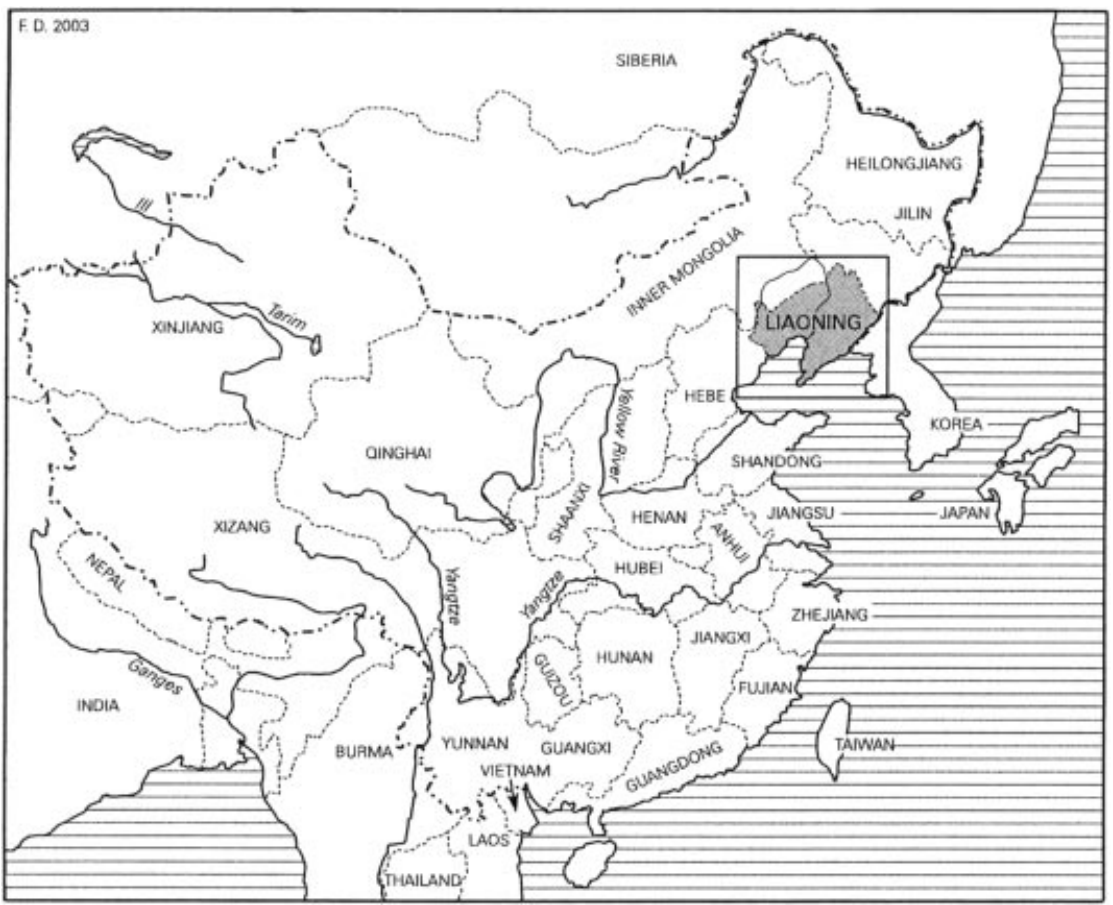

Figure I. Liaoning province

played a role in their success. ${ }^{2}$ Even if positions were not transmitted directly from father to son, members of certain kinship networks had a powerful advantage when it came to launching their sons into official careers. Those who were not members of such networks were shut out. Society, as a result, was more "closed" than would be apparent from an analysis of the association between fathers' and sons' outcomes.

The extent of social mobility in rural China before the twentieth century is even less clear. It used to be assumed that local society was more static than elite society. Climbing the lowest rungs of the ladder of success was difficult because families needed to accumulate substantial resources before they could even consider such mobility strategies as the education of their sons. Locally prominent families, meanwhile, could make use of their economic, political, and social resources to maintain their position from one generation to the next. Recent evidence, however, suggests that the picture may have been more complex. Preliminary analysis of data on the residents of Daoyi, a state-farm system located in what is now 
Liaoning province, suggests that, during the nineteenth century, most of the men who held official titles were from undistinguished backgrounds in that neither their fathers nor their grandfathers had ever held titles. ${ }^{3}$ An extension of this work that considered roles for other co-resident male kin confirmed the conclusion that large proportions of the men who acquired titles were from households where no-one had ever held one. ${ }^{4}$

The data and methods normally used to study intergenerational social mobility are not likely to resolve the issue to everyone's satisfaction. One of the most frequently noted features of Chinese society was the importance of the extended family, including distant kin. As Hymes argued, even if the sons of successful imperial examination candidates had only a slight advantage when it came to succeeding in the examinations themselves, there may have been networks of kin that were disproportionately successful at securing opportunities for their members. Similarly, in rural Liaoning, even if the possession of an official title by father or other co-resident kin had only a mild effect on the chances that a male would attain a title, the results in Lee and Campbells cannot rule out the possibility that members of particular lineages nevertheless accounted for most of the men with official titles. Similarly, the results in Lee and Campbell ${ }^{6}$ cannot rule out a role for transmission between related males living in separate households. In situations where the transmission of status from one generation to the next was highly diffuse, only a weak association between the outcomes of father and son would be apparent, even if most or all of the men who succeeded on the examinations or attained titles were from a relatively small number of families.

To account for the potential role of kin networks in determining mobility outcomes in late imperial China, we apply quantitative methods to nominative, longitudinal population-register data. The populationregister data cover a population of largely rural residents of Liaoning province in northeast China from I749 to I909. They allow for identification of the paternal kin of an individual even if they are distantly related. Measurement of the characteristics of kin is thus straightforward. We apply discrete time-event history techniques to examine how the possession of titles by various kin affected the chances that a male would attain an official title. We focus on the effects of possession of title by fathers, uncles, fathers' first cousins, and fathers' second cousins. We test directly the hypothesis that society was more closed than it appears from

3. James Lee and Cameron Campbell, Fate and Fortune in Rural China (Cambridge, 1997), pp. I96-2I4.

4. Cameron Campbell and James Lee, "Family Background and Attainment of Banner Status in Northeast China, I789-1909" (Presented at the meeting of the ISA RC 28 Committee on Social Stratification and Mobility, I 8-20 August 2000, Calgary, Canada).

5. Lee and Campbell, Fate and Fortune, pp. 196-214.

6. Campbell and Lee, "Family Background". 
the association between fathers' and sons' outcomes, because men could also "inherit" high status from senior kin other than their fathers. We also examine whether or not there was clustering among related men of the same generation, holding the characteristics of the senior generation constant. From these results, we can whether opportunities were available to all men or monopolized by particular kin networks.

These results will further illuminate interactions between kin living in separate households in historical China. A distinguishing feature of the longitudinal population registers is that by chaining together the links between parents and children, we generate genealogies for individuals and identify their distant kin. In contrast with Campbell and Lee, ${ }^{7}$ which only considered co-resident kin, here we identify kin who lived in separate households and examine how their characteristics affected the chances that a male would attain a title. Extending on a line of inquiry initiated in Campbell and Lee, ${ }^{8}$ for these distant kin we examine whether or not coresidence conditioned the effects of attaining a title.

These results will showcase the potential of longitudinal population register data to open up a new avenue for inquiry in the analysis of social mobility. Until now, almost all studies of intergenerational social mobility, whether historical or contemporary, have focused on the influence of parents' characteristics on children's outcomes, and to some extent the associations between siblings' outcomes. This partly reflects the limitations of the available data. The surveys that are the basis for most analyses of contemporary social mobility rarely provide detail on kin of the respondent other than their siblings and parents. Similarly, historical studies of social mobility have focused almost exclusively on associations between the outcomes of fathers and sons, and failed to address the possibility that kin other than the father affected the attainment of status. 9

The remainder of the paper is divided into four sections. The first section reviews in more detail debates and findings on social mobility in China. Because the sociological literature on mobility in China is sparse, we will consider both contemporary and historical evidence. The second and third sections introduce the data and methods, respectively. The fourth section presents and discusses results. To facilitate interpretation, we present simulation results along with the coefficients estimated in the

\section{Ibid.}

8. Cameron Campbell and James Lee, "Connections Within and Between Households in Rural Liaoning, 1789-1909”, California Center for Population Research Working Paper CCPR-০oI○. Available at www.ccpr.ucla.edu.

9. Ronald Aminzade and Randy Hodson, "Social Mobility in a Mid-Nineteenth Century French City", American Sociological Review, 47 (1982), pp. 44I-457; Nancy S. Landale and Avery M. Guest, "Generation, Ethnicity, and Occupational Opportunity in Late NineteenthCentury America", American Sociological Review, 55 (1990), pp. 280-296; Allan Sharlin, "From the Study of Social Mobility to the Study of Society", American Journal of Sociology, 85 (1979), pp. $338-360$. 
event-history analysis. The simulations yield the percentages of men from different backgrounds expected to ever attain a title in the course of their lifetime. They are also used to work out the distribution of backgrounds for the men who do attain titles. The paper concludes with a discussion of the implications of the findings for our understanding of kinship and social mobility in historical Chinese society.

\section{B A C K GROUND}

Late imperial Chinese society is widely noted for the emphasis by the state on achieved, not ascribed, characteristics in the recruitment and promotion of high-level officials. The Tang dynasty (670-906 AD) saw the elimination of the hereditary aristocracy. From the Song dynasty (960I $27 \mathrm{AD}$ ) onward, officials were chosen through examinations open to almost all educated men. By the middle of the Qing (I644-I9I I AD), there were no more officially recognized hereditary status distinctions, except for special situations such as membership in the imperial lineage, the Eight-Banner system, and ethnicity. When it came to attaining an elite official title, ancestry should in theory only have mattered indirectly, in that those from a privileged background were more likely to be educated and therefore successful on imperial examinations.

The relatively few empirical studies of social mobility in historical China confirm that men of undistinguished parentage did indeed have a chance to attain official titles. According to one classic analysis of the family backgrounds of successful candidates on the two highest level imperial examinations during the Ming (1368-1644 AD) and Qing, in the period of peak mobility in the sixteenth century as many as one-half of successful candidates were "new men", in the sense that neither their fathers nor their grandfathers had held a degree of any sort. ${ }^{10}$ While certain families were consistently successful at launching their sons into official careers, there appears to have been room at the top for men from less distinguished families, and accordingly a steady infusion of new blood.

The few available quantitative studies for rural Chinese populations before the twentieth century also suggest that society was open. For that community, analysis of household registers showed that over one-half of the men who attained a state occupation were the sons of men who had never held one. ${ }^{\text {II }}$ One-third of men who attained a state occupation not only had a father who had never held an occupation, but had never lived with anyone who had ever held one. This preliminary study, based as it was on simple bivariate tabulations, did not measure the influence of the

I0. Ho, The Ladder of Success, pp. 92-125.

I I. Lee and Campbell, Fate and Fortune, p. 205. 
experiences of fathers and other kin, nor did it attempt to measure how successful men with status were at transmitting their status to their sons. A more refined analysis of an expanded dataset that applied multivariate event-history techniques to distinguish between the effects of different coresident kin reached a similar conclusion. ${ }^{\mathrm{I}}$ While the possession of a title by senior male kin other than the father increased the chances that a male would acquire one himself, there was little evidence that particular households monopolized titles. Depending on the type of title considered, between one-half and two-thirds of men who acquired titles appear to have been "new" in the sense that no one present in the household had ever held one.

What little evidence exists for China during the middle of the twentieth century hints that it may have been relatively "open" by the standards of other societies. While results likely reflect the strong emphasis by the postI949 state on egalitarianism in the allocation of educational and occupational opportunities, we note them here to provide some background. The clearest evidence is from analysis of educational attainment. In an analysis of 1982 Chinese census data on men in multigenerational households, Deng and Treiman ${ }^{13}$ found that the influence of the father's educational attainment on their own educational attainment for men born in the I940s was half as strong as in other countries. As for occupational mobility, one study revealed that even though the high proportion of farmers in the population led to a low rate of total mobility, the vast majority of holders of high-status occupations were the children of parents in low-status occupations. Less than 20 per cent of professionals, for example, were the children of professionals. Roughly half were the children of farmers. ${ }^{\mathrm{I}}$

Agreement about the openness of historical Chinese society is by no means universal. One detailed study of elites in a southern Chinese community during the Song dynasty claimed that many of the men who succeeded in the imperial examinations, even though their fathers or grandfathers were undistinguished, had been assisted by distant kin who had been successful. ${ }^{15}$ Members of certain kin networks, in other words, had a substantial advantage when it came to taking the examinations and starting on official careers. Those who were not fortunate enough to be

I2. Campbell and Lee, "Family Background".

I3. Zhong Deng and Donald J. Treiman, "The Impact of the Cultural Revolution on Trends in Educational Attainment in the People's Republic of China”, American Journal of Sociology, ro 3 (I997), pp. 39I-428.

I4. Yuan Cheng and Jianzhong Dai, "Intergenerational Mobility in Modern China", European Sociological Review, I I (1997), pp. 17-35, 24.

is. Hymes, Statesmen and Gentlemen, pp. 29-62. 
born into such networks had limited opportunities for advancement, and in this sense society was "closed". ${ }^{16}$

The large literature on kinship in Chinese society tends to confirm that networks based on family relationship had the potential to affect mobility outcomes. In the early part of the twentieth century, Lang ${ }^{17}$ and others identified the importance of kin networks as an obstacle to economic development in China because the intense pressure on individuals with influence over hiring decisions to take care of their relatives spawned nepotism and particularism. More recently, Greenhalgh, ${ }^{18}$ Whyte, ${ }^{19}$ Wong, ${ }^{20}$ and others have suggested that strong ties between kin, coresident and non-co-resident, contributed to rapid economic growth in Greater China from the I 970 s onwards. Kin are claimed to be sources of reliable employees, capital, contacts, and information. Anthropologists, of course, have written extensively on the role of lineages, especially in south China. ${ }^{21}$ In the past, well-organized lineages provided educational and other opportunities to their members. More recently, Bian ${ }^{22}$ showed that in urban China in the I980s, individuals relied heavily on their social networks, including their kin, to secure economic opportunities in an environment where jobs were almost all assigned by the state.

In our analysis, accordingly, we will distinguish between two opposing hypotheses about the extent of intergenerational social mobility in rural Liaoning. On the one hand, if official titles in this rural population were allocated according to the same merit-oriented principles as official titles among the national elites, inheritance should have been relatively weak. Simulation results should reveal low probabilities that the sons of men with titles would acquire titles themselves, and high probabilities that the men who did acquire an official title had no kin, co-residing or not, who held an official titles. On the one hand, if particular networks of kin were

I6. It is unclear how much to make of Hymes's (I 986) conclusions, however, since he cast a wide net when identifying distant kin who may have helped men at their examinations. It is entirely possible that any random sample of men from elite families would exhibit the same proportions with successful distant kin as his sample of successful examination candidates.

17. Olga Lang, Chinese Family and Society (New Haven, CT, 1946), pp. i8 I-192.

18. Susan Greenhalgh, "Families and Networks in Taiwan's Economic Development", in E. Winckler and S. Greenhalgh (eds), Contending Approaches to the Political Economy of Taiwan (Armonk, NY, 1988); Susan Greenhalgh, "Land Reform and Family Entrepreneurialism in East Asia", Population and Development Review, is Supplement (I990), pp. 77-i I 8.

19. Martin K. Whyte, "The Social Roots of China’s Economic Development", China Quarterly, I44 (1995), pp. 999-1019.

20. S.L. Wong, "The Chinese Family Firm: A Model”, British Journal of Sociology, 36 ( 1985 ), pp. 58-72; idem, "The Applicability of Asian Family Values to Other Sociocultural Settings", in P. Berger and H.H.M. Hsiao (eds), In Search of an East Asian Development Model (New Brunswick, NJ, I988), pp. I34-I54.

2. Maurice Freedman, Chinese Lineage and Society: Fukien and Kwangtung (New York, 1966). 22. Yanjie Bian, "Bringing Strong Ties Back In: Indirect Ties, Network Bridges, and Job Searches in China”, American Sociological Review, 62 (1997), pp. 366-385. 
especially successful at securing titles for their members, then even if father-son inheritance was weak, most of the men who acquired titles should at least have had distant kin who held titles, perhaps living in other households.

We will assess fluidity by comparing rates of downward mobility among the sons of elites and the proportions of elites who are "new blood" to published results on other historical populations, mainly in North America and Europe. Over the past few decades, a number of studies of intergenerational mobility in the past have appeared. ${ }^{23}$ These studies, like this one, mostly focused on specific populations that are not nationally representative. Many of these populations are not ideal for comparison because they were urban. In some cases, they were subsets of an urban population. The population analysed here, of course, is rural.

The goal in carrying out such a comparison is not to make a definitive statement about whether China, or rural Liaoning, was more or less fluid than the West, but rather to help assess claims by $\mathrm{Hymes}^{24}$ and others about the rigidity associated with the importance of kinship networks in attaining elite positions. If $\mathrm{Hymes}^{25}$ is correct, we should find that downward mobility among men whose fathers or other senior kin held title was much less than in other historical populations. More importantly, the proportion of titleholders in each generation who are "new", in the sense of not having any senior relatives who also hold titles, should be much lower than the proportion of elites in other populations who are "new" in the sense of having undistinguished fathers.

We also seek to distinguish between two hypotheses about the nature of relationships between kin living in separate households. On the one hand, the common understanding that the descent group or lineage played an important role in structuring individual outcomes in historical China leads to an expectation that the influence of the characteristics of kin should have been independent of whether or not they actually resided in the same household. On the other hand, empirical results on the influence of

23. Aminzade and Hodson, "Social Mobility"; Clyde Griffen and Sally Griffen, Natives and Newcomers: The Ordering of Opportunity in Mid-Nineteenth-Century Poughskeepsie (Cambridge, 1978); Landale and Guest, "Generation, Ethnicity, and Occupational Opportunity"; Hartmut Kaelble, Historical Research on Social Mobility: Western Europe and the USA in the Nineteenth and Twentieth Centuries (New York, 1981); Michael B. Katz, The People of Hamilton, Canada West: Family and Class in a Mid-Nineteenth-Century City (Cambridge, 1975); Andrew Miles, Social Mobility in Nineteenth- and Early Twentieth-Century England (New York, 1999); Andrew Miles and David Vincent (eds), Building European Society: Occupational Change and Social Mobility in Europe 1840-1940 (New York, 1993); Sharlin "From the Study of Social Mobility"; Stephan Thernstrom, The Other Bostonians: Poverty and Progress in the American Metropolis, I880-1970 (Cambridge, 1973).

24. Hymes, Statesmen and Gentlemen, pp. 29-62.

25. Ibid. 
characteristics of kin on male marriage chances in Campbell and Lee ${ }^{26}$ suggest that, at least in Liaoning, the residential household may have been more important than the lineage as a unit of social and economic organization. In that analysis, the characteristics of kin affected the marriage chances of a male only if the kin resided in the same household. The characteristics of kin living outside the household had no influence on marriage chances.

\section{A T A}

Our study focuses on a population of hereditary tenants who lived on state farms in Liaoning province in northeast China during the eighteenth and nineteenth centuries. These hereditary tenants were the descendants of Han Chinese settlers recruited by the state to move from Shandong Province in the late seventeenth century and repopulate the Chinese northeast, which had been emptied in the course of the Ming-Qing transition in the first half of the seventeenth century. The settlers were given the right to farm land controlled by the Eight Banners, a civil and military administration that was a key part of the Qing state. Each was associated with one of several dozen separately registered state farm populations. In terms of their institutional context, these tenants are perhaps most comparable to tenants on crown lands in historical Europe. They did have some distinguishing features. In particular, though they could not move from the state lands, they could move within them.

For the purposes of this analysis the most important feature of these state-farm tenants is that their association with the Eight-Banner system made them eligible for official titles. There were altogether five categories of official title: banner, civil service, examination, honorary, and household group leader. The first three categories were formal governmental offices and often included a generous salary and other perquisites. Banner titles were associated with position in the Eight-Banner system, while civil service titles were associated with positions elsewhere in the bureaucracy. Examination titles came with success in the official examinations. The fourth category, honorary titles, were typically purchased. They are indicative of individual or family wealth. The fifth category, household group leader, or zuzhang, is by far the most common and refers to an unsalaried position at the lowest level of local banner administration. We do not consider it in our analysis.

Possession of an official title was the most important source of privilege in this society, so that titleholders constituted an elite. ${ }^{27}$ They accounted for roughly s per cent of adult males in the populations studied here at any 
given time. While we do not have detailed data on the specific salary and perquisites associated with each title, we know that they were often sufficient to support several families, and came both in cash and in kind. The privilege associated with holding a title is reflected in the data in important demographic outcomes. ${ }^{28}$ Titleholders and their sons married earlier and in higher proportions, and once married, had more children. While in implications of holding a title for men and their immediate kin are clear, our analysis of the implications for more distant relatives is ongoing.

The state-farm tenants lived in approximately 400 distinct communities scattered across a swath of land in Liaoning equivalent in size to the Netherlands. Figure 2 summarizes the geographic distribution of observations, with each circle corresponding to a community and its size corresponding to the number of observations it contributed. The swath ran from the coast of the Bohai Gulf on the Liaodong Peninsula in southwest Liaoning all the way to a hilly and remote region in the northwest of the province. The southern state-farm systems were all located in or near what is now Gaiping county on the Liaodong Peninsula. They were either on or close to the coast of the Bohai Gulf. They were close to Yingkou, which became a treaty port open to international trade in I 858 . The northern state farms lay were scattered in a belt that ran from what is now the provincial capital, Shenyang, to a hilly and remote region in the northeast of the province.

The data on the tenants is derived from "Household and Population Registers of the Eight-Banner Han Army" (Hanjun baqirending bukou ce). This source is described in detail in Lee and Campbell, ${ }^{29}$ which also provides additional background on the population. The household registers were compiled on a triennial basis for a number of Han banner populations living on state farms in the northeast and certain other locations from the early eighteenth century until i909. The Qing relied heavily on these registers for civilian and military administration of these populations. They accordingly devised a system of internal crosschecks to ensure consistency and accuracy. First, they assigned every person in the banner population to a residential household (linghu) and registered them on a household certificate (menpai). Then they organized households into clans (zu), and compiled annually updated clan genealogies (zupu). Finally, every three years they compared these genealogies and household certificates with the previous household register to compile a new register. They deleted and added people who had exited or entered in the last three years and updated the ages, relationships, and official titles of those people who remained. Each register, in other words, completely superseded its predecessor. 


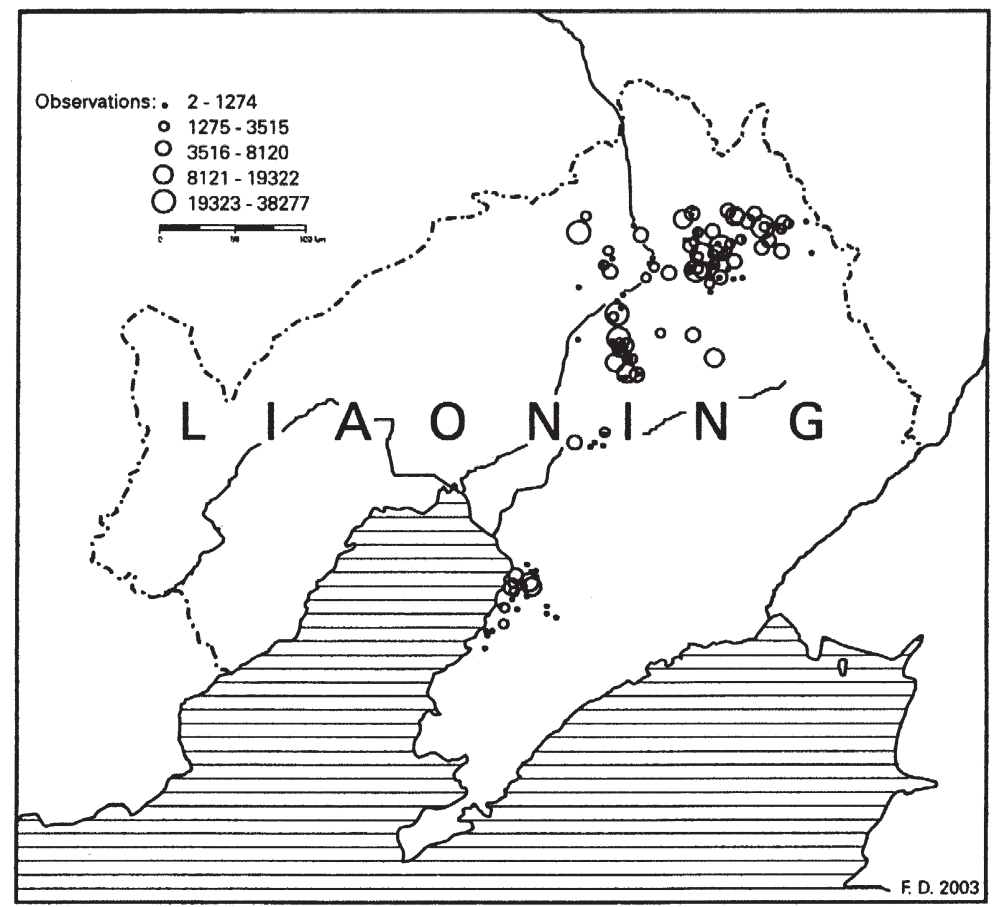

Figure 2. Eight-Banner Household Registration Data, Liaoning, I749-1909

The banner registers provide far more comprehensive and accurate demographic and sociological data than the household registers and lineage genealogies common elsewhere in China. ${ }^{30}$ This is because the northeast, which was the Qing homeland, was under special state jurisdiction, distinct from the provincial administration elsewhere. Regimentation of the population actually began as early as I625, when the Manchus made Shenyang their capital and incorporated the surrounding communities into the banner system. ${ }^{3 \mathrm{I}}$ By the late eighteenth century, not only was the population registered in remarkable precision and detail, migration was strictly controlled, not just between northeast China and China proper, but between communities within northeast China as well.

30. Stevan J. Harrell, "On the Holes in Chinese Genealogies", Late Imperial China, 8 (1987), pp. 53-79; Tao Jiang, Zhongguo jindai renkou shi [Modern Population History of China], (Zhejiang renmin chuban she, 1993); William G. Skinner, "Sichuan's Population in the Nineteenth Century: Lessons from Disaggregated Data”, Late Imperial China, 8 (1987), pp. I-79; Ted A. Telford, "Patching the Holes in Chinese Genealogies", Late Imperial China, I I (1990), pp. I I6I35.

3I. Yizhuang Ding, Qingdai baqi zhufang zhidu yanjiu [The Qing Eight-Banner Garrison System] (Tianjin, I992); Mark C. Elliott, The Manchu Way: The Eight Banners and Ethnic Identity in Late Imperial China (Stanford, CA, 200I). 
Government control over the population was tighter than in almost any other part of China. Indeed, individuals who departed from the area without permission were actually identified in the registers as "escapees" (taoding). As a result, the Eight-Banner household registers are the most extensive and detailed records of a any rural Chinese population in the late imperial period. ${ }^{32}$

The registers record at three-year intervals for each person in the target population the following information in order of appearance: official title (if any); relationship to the household head; name(s); adult banner status; age in sui; animal birth year; lunar birth month, birthday, and birth hour; marriage, death, or emigration, if any, during the intercensal period; physical disabilities, if any, and if the person is an adult male; name of their kin-group head; banner affiliation; and village of residence. Individuals are listed one to a column in order of their relationship to the head, with his children and grandchildren listed first, his co-resident siblings and their descendants listed next, and then uncles, aunts, and cousins. Wives are always listed immediately after their husbands, unless they are superceded by a co-resident widowed mother-in-law.

The registers are distinguished by the possibilities for record linkage across time and between kin. Individuals can be followed very easily from one register to the next because they appear in almost the same order in successive registers. Accordingly, it is relatively straightforward to reconstruct life histories and generate variables describing such past characteristics as whether or not a male had previously held a title. Perhaps more importantly, by comparison of observations for the same individual in successive registers, we can construct outcome measures indicating whether or not particular events took place in a particular time interval. For this analysis, as described later, we construct indicators of whether or not males acquire official titles between one register and the next.

The extensive detail on household relationship, meanwhile, allows for reconstruction of genealogies and identification of kin living in the same or different households. Our basic procedure is to chain together the links between fathers and sons to identify grandfathers, great-grandfathers, and more distant male ancestors. Table I summarizes the numbers of generations back for which it is possible to trace the men recorded in the observations. Males whose grandfathers can be identified accounted for slightly more than two-thirds of the observations. Males whose greatgrandfathers can be identified accounted for nearly one-half of the observations. How far back an individual's ancestry may be traced depends largely on when they lived. Many of the men who were born in the last decades of the nineteenth century or the first decade of the twentieth can have their ancestry traced back six or seven generations.

32. Lee and Campbell, Fate and Fortune, pp. 223-237. 
Table I. Percentages of observations of males linked to paternal ancestors

\begin{tabular}{lc}
\hline Ancestor & Percentages of male observations linked \\
\hline Father & 84.21 \\
Grandfather & 68.79 \\
Great-grandfather & 48.42 \\
Great-great-grandfather & 29.04 \\
Great-great-great-grandfather & 5.62 \\
\hline Number of observations & 362,090 \\
\hline
\end{tabular}

Since most of the men who were already adults in the earliest registers had already lost their fathers and grandfathers, they accounted for most of the men whose ancestry could not be traced.

Once we constructed genealogies, it was a straightforward matter of data processing to link men to their brothers, cousins, first cousins, second cousins, and even more distant kin and measure their characteristics. Because the registers identify who lives with whom, we can further distinguish between co-resident and non-co-resident. For men whose grandfathers can be identified, we can locate uncles and cousins. For men whose great-grandfathers can be identified, we can locate second cousins and fathers' cousins. In all cases, we are restricted to paternal kin. While the registers record men's wives, they do not allow them to be traced back to their natal families.

The data we analyze are a subset from a sample of registers we have compiled that consist of 705,355 observations of $\mathrm{I} 29, \mathrm{I} 80$ individuals who lived in I4 separately registered state farm populations in Liaoning province. Restrictions dictated by the methods described in the next section permit analysis of only 78, 106 of the 607, I63 observations from I I state-farm populations. ${ }^{33}$ First, we only include observations of males aged I I to 50 sui, that is, roughly Io to 49 Western years of age. ${ }^{34}$ Males outside this age range almost never acquired official titles. Females, meanwhile, were not eligible for titles. Second, we can only include observations from after 1789 because the registers from before that year do not distinguish

33. In this particular analysis, we restrict our analysis to eleven populations of regular bannermen (zhengshen qiren) under what were called the three banner commanders (san zuoling xia). We exclude three departmental privy purse, or guangchusi, populations who were responsible for such specialized production as honey, cotton, and fish. They were administered separately and accordingly behaved differently (Yizhuang Ding, Guo Songyi, James Lee, and Cameron Campbell, Liaodong yimin de qiren shehui [Banner Society and the Settlement of Eastern Liaodong], book manuscript, 200I). Most importantly for the purposes of this analysis, most of the men in these populations appear not to have been eligible for official titles.

34. In the Chinese system of age reckoning, individuals were I sui at birth, and their age was incremented every lunar new year. Ages reckoned in sui are on average I.5 higher than ages reckoned according to the Western standard. 
individuals by their residential household. Thus we cannot distinguish coresident from non-co-resident kin in the registers before 1789 . Third, the need to identify the time periods in which titles were acquired requires that we restrict to observations of males for which observations are also available three or six years hence. Fourth, since we are interested in how the characteristics of second cousins and fathers' cousins affect the chances of attaining a title, we only consider observations of males whose fathers, grandfathers, and great-grandfathers could all be identified. Finally, since we are interested in the factors that influence the chances of acquiring a title between the current and next register, we exclude observations of males who currently hold titles.

\section{METHODS AND MEASURES}

To measure the influence of own and family characteristics on the chances of acquiring an official title, we use a discrete time-event-history approach. An event-history approach has several advantages for the study of mobility, most notably the ability to account for the effects of changes over time in individual characteristics and the macrosocial context. ${ }^{35}$ In particular, we use complementary log-log regression, the discrete-time approach that yields results most comparable to those from continuoustime approaches. ${ }^{36}$ The following equation summarizes the basic model:

$$
f(p)=\beta_{\circ}+\mathbf{b X}
$$

The transformed probability $p$ of an outcome of interest is expressed as a linear function of a set of right-hand side variables $\mathrm{X}$ that measure individual and family characteristics. Estimated coefficients $b$ measure the strength of the association between these variables and the complementary $\log -\log$ of the outcome of interest. A positive coefficient indicates that higher values of the associated right-hand variable of interest are associated with increased chances of the outcome. A negative coefficient indicates an inverse association. A coefficient close to zero suggests a lack of association. Tests of statistical significance help indicate whether differences between estimated coefficients and zero are large enough to reject the null hypothesis that there is no relationship and that the observed coefficient might be the result of random variation in the data.

35. Harry B.G. Ganzeboom, Donald J. Treiman, Wout C. Utlee, "Comparative Intergenerational Stratification Research: Three Generations and Beyond", Annual Review of Sociology, I7 (1991), pp. 277-302. See Andrew G. Walder, Bobai Li, and Donald Treiman, "Politics and Life Chances in a State Socialist Regime: Dual Career Paths into the Urban Chinese Elite, 1949 to 1996", American Sociological Review, 65 (2000), pp. 191-209 for an application of event-history techniques to the study of social mobility.

36. J. Scott Long, Regression Models for Categorical and Limited Dependent Variables (Thousand Oaks, CA, I997), pp. 51-52. 
Table 2. Means and standard deviations of the variables used in the analysis, Liaoning, $1789-1909$

\begin{tabular}{lcc}
\hline Variable & Mean & $\begin{array}{c}\text { Standard } \\
\text { deviation }\end{array}$ \\
\hline Attain title by next register & & \\
Dataset (reference: Daoyi) & 0.007 & \\
Gaizhou & 0.060 & \\
Chengnei & 0.014 & \\
Feicheng Yimiancheng & 0.133 & \\
Gaizhou Manhan & 0.044 & \\
Dadianzi & 0.083 & \\
Guosantun & 0.067 \\
Bakeshu & 0.045 & \\
Daxingtun & 0.185 & \\
Nianma Dahai & 0.095 & \\
Changzhaizi & 0.063 & \\
Age (reference: 11-20 sui) & & \\
21-30 sui & 0.293 & \\
31-40 sui & 0.218 & \\
41-50 sui & 0.156 & \\
Year-1800 & 57.329 & 26.940 \\
Post-1860* (year-1860) & 9.814 & 14.250 \\
Titles & & \\
Father has title & & \\
\# Co-resident uncles with title & 0.044 & \\
\# Co-resident fathers' cousins with title & 0.047 & 0.244 \\
\# Non-co-resident fathers' cousins with title & 0.030 & 0.237 \\
\# Brothers with title & 0.035 & 0.229 \\
\# Co-resident cousins with title & 0.022 & 0.168 \\
\# Co-resident second cousins with title & 0.032 & 0.229 \\
\# Non-co-resident second cousins with title & 0.011 & 0.142 \\
Other family and bousebold characteristics & 0.039 & 0.252 \\
Eldest brother in sibset & & \\
\# Living brothers in sibset & 0.680 & 0.467 \\
\# Males in the household & 0.991 & 1.086 \\
Next register is 6 years away (reference: 3 years) & 7.543 & 6.283 \\
N & 0.179 & \\
\hline
\end{tabular}

For our outcome variable, we use an indicator of whether or not a male currently without an official title acquires one by the time they are next observed. ${ }^{37}$ Table 2 reveals that too. We only consider acquisition of titles in the four categories that, according to the earlier discussion, were clearly

37. In previous analyses we have distinguished among the different types of official title (Lee and Campbell, Fate and Fortune, p. I69; Campbell and Lee, "Family Background"). We avoid doing so here to keep the results on the role of different kin easy to interpret. 
associated with privilege: banner, civil service, examination, and honorary. Since we restrict to observations where either the immediately following register or the one after that is available, this amounts to an indicator of whether or not a male acquires a title in the next three or six years. Because the length of time until the next available observation will be positively associated with the chances of acquiring an official title, we include as an explanatory variable a dichotomous indicator of whether or not the next observation is six years away instead of three. To measure the role of family background in determining mobility outcomes, we include as explanatory variables counts of the numbers of senior kin who hold official titles. Table 2 summarizes them. To measure "classic" father-son inheritance, we include an indicator of whether or not the father has a title. To account for the possibility that men could be advantaged by the presence of other kin with titles, we include similar variables for other male kin. For uncles, we count the number who co-resided who held official titles. We have no variable for non-co-resident uncles because there were too few of them. Even elderly men almost always lived with any surviving brothers they had. For fathers' cousins with titles, we include separate counts according to whether or not they co-reside.

To assess openness, we examine outflows and inflows calculated from simulations that use the estimated coefficients as inputs. For outflows, we construct a life table from the predicted probabilities of attaining a title at each age, and work out the chances that a man would obtain a title if he survived to age fifty sui. If this simulation indicated that most men whose fathers or other senior kin held official titles acquired a title themselves, the interpretation would be that certain kin networks were very successful at securing opportunities for their junior members. From this perspective, society would appear "closed". On the other hand, if most of the men whose fathers or other senior kin held official titles failed to acquire titles of their own, that would indicate the presence of substantial downward mobility, and suggest that society was "open". For inflows, we calculate predicted probabilities of attaining a title for each of the men in the population, and from these work out the distribution of family backgrounds for the sub-population of men who have a title. If most of the men who acquired official titles appeared to have senior kin who already held a title, the indication would be that society was closed. If most of the men who acquired titles had no senior kin who already held titles, the indication would be that society was open.

To examine whether or not there was clustering among related males of the same generation in the acquisition of titles, we include counts of the numbers of kin of the same generation with official titles. The goal is to assess whether or not some kin networks were better than others at securing titles for their members, even when the characteristics of the senior generation are held equal. We include variables for the numbers of 
co-resident brothers and cousins with titles. There were almost no non-coresident brothers and too few non-co-resident cousins to warrant including variables for them. We also include separate counts of coresident and non-co-resident second cousins with titles. Positive coefficients on these variables would indicate the presence of clustering. While clustering would not indicate that society was "closed" in the classic sense, it would indicate that kin networks were important.

We also examine whether or not other characteristics of the family played a role. To test whether or not families positioning male members for the acquisition of a title favored eldest sons, we include an indicator of whether or not the man was the eldest surviving brother in a sibset. To test whether larger families and households had an advantage when it came to acquiring titles for their members, we include a count of the number of brothers in the male's sibset, and a count of the number of working-age males in the household. We expect men in larger households to have had an advantage because such households appear to have been better off $3^{8}$ and may also have had more extensive social networks.

We include a variety of other controls to ensure that apparent effects of the substantively interesting variables are not being driven by changes and differences in the composition of the population under study. To account for variation between state-farm systems in the probability of attaining a title, we included a dummy variable for each state-farm system except one, Daoyi, which was the reference category. We control for age with a categorical variable.

To account for temporal trends in the structure of opportunities, we include controls for year. Visual inspection of the probabilities of acquiring a title in successive registers revealed that they declined steadily after i 860 , we allowed for a change in slope in that year. To achieve this, we included two variables. 39 One was year, measured from i 800 . The coefficient for this variable reflects the average annual change in the probability of attaining a title until i 860 . The second was $\circ$ until i 860 . After I 860 , it was set to the number of years since $1860.4^{\circ}$ Summing this coefficient with the first yields the average annual change in the probability of attaining a title after I 860 .

\section{RESULTS}

Secular trends in the chances of attaining a title reflect the declining fortunes of the Qing state in the latter half of the nineteenth century.

38. Lee and Campbell, Fate and Fortune, pp. 133-156.

39. In technical terms, we introduced a linear spline with a knot at I 860 .

40. In current work we are exploring whether this change in the chances of attaining a title was associated with a reduction of fluidity by interacting the variable for post-I 860 with the numbers of kin with title. 
Table 3. Complementary log-log regression of effects of senior kin characteristics on title attainment, Liaoning, 1789-1909

\begin{tabular}{|c|c|c|c|c|c|c|}
\hline \multirow[t]{2}{*}{ Variable } & \multicolumn{2}{|c|}{ Model 1} & \multicolumn{2}{|c|}{ Model 2} & \multicolumn{2}{|c|}{ Model 3} \\
\hline & Coeff. & $\mathrm{P}$ & Coeff. & $\mathrm{P}$ & Coeff. & $\mathrm{P}$ \\
\hline \multicolumn{7}{|l|}{ Dataset (reference: Daoyi) } \\
\hline Gaizhou & -0.460 & 0.12 & -0.454 & 0.13 & -0.428 & 0.15 \\
\hline Chengnei & 0.122 & 0.63 & 0.093 & 0.71 & 0.131 & 0.60 \\
\hline Feicheng Yimiancheng & -0.797 & 0.00 & -0.781 & 0.00 & -0.761 & 0.00 \\
\hline Gaizhou Manhan & 0.753 & 0.00 & 0.680 & 0.00 & 0.703 & 0.00 \\
\hline Dadianzi & -0.639 & 0.00 & -0.619 & 0.00 & -0.580 & 0.01 \\
\hline Guosantun & 0.112 & 0.50 & 0.097 & 0.55 & 0.102 & 0.53 \\
\hline Bakeshu & 0.375 & 0.05 & 0.351 & 0.07 & 0.345 & 0.07 \\
\hline Daxingtun & -0.433 & 0.00 & -0.425 & 0.00 & -0.406 & 0.00 \\
\hline Nianma Dahai & -1.021 & 0.00 & -1.006 & 0.00 & -0.980 & 0.00 \\
\hline Changzhaizi & 0.323 & 0.06 & 0.325 & 0.06 & 0.353 & 0.04 \\
\hline \multicolumn{7}{|l|}{ Age (reference: $11-20$ sui) } \\
\hline $21-30$ sui & 0.413 & 0.00 & 0.430 & 0.00 & 0.427 & 0.00 \\
\hline $31-40$ sui & 0.113 & 0.38 & 0.149 & 0.25 & 0.135 & 0.30 \\
\hline $41-50$ sui & -0.078 & 0.64 & -0.041 & 0.81 & -0.050 & 0.77 \\
\hline Year-1800 & 0.001 & 0.70 & 0.001 & 0.86 & 0.001 & 0.77 \\
\hline Post-1860* (year-1860) & -0.020 & 0.01 & -0.019 & 0.01 & -0.020 & 0.00 \\
\hline Next register 6 years away & 0.747 & 0.00 & 0.764 & 0.00 & 0.751 & 0.00 \\
\hline \multicolumn{7}{|l|}{ Titles } \\
\hline Father has title & 2.090 & 0.00 & 1.989 & 0.00 & 1.953 & 0.00 \\
\hline $\begin{array}{l}\text { \# Co-resident uncles with } \\
\text { title }\end{array}$ & & & 0.375 & 0.00 & 0.370 & 0.00 \\
\hline $\begin{array}{l}\text { \# Co-resident fathers' } \\
\text { cousins with title }\end{array}$ & & & & & -0.092 & 0.42 \\
\hline $\begin{array}{l}\text { \# Non-co-resident } \\
\text { fathers'cousins with title }\end{array}$ & & & & & 0.389 & 0.00 \\
\hline Intercept & -5.363 & & -5.375 & & -5.415 & \\
\hline $\mathrm{N}$ & 78,106 & & 78,106 & & 78,106 & \\
\hline
\end{tabular}

According to the results for the temporal variables in Table 3 , the chances of attaining a title were stable until i 860. After I860, the chances of attaining an official title declined steadily, by about 2 per cent per year. The implication is that between 1860 and the first decade of the twentieth century, the chances of attaining a title were more than halved. This decline was driven by a dramatic reduction in the availability of Banner titles, which were associated with salaries and other perquisites. The chances of attaining an honorary title, many of which were purchased, actually increased. ${ }^{\mathrm{I}}$

4I. In our current work we are examining these temporal trends, including their sources and implications, in much more detail. 
Table 4. Predicted probabilities of attaining a title by age 50 sui according to the characteristics of senior kin, Liaoning, I789-1909

\begin{tabular}{lccc}
\hline Father has title & $\begin{array}{c}\text { Co-resident uncles } \\
\text { with title }\end{array}$ & $\begin{array}{c}\text { Non-co-resident } \\
\text { fathers' cousins } \\
\text { with titles }\end{array}$ & $\begin{array}{c}\text { Percentage of men } \\
\text { attaining a title by } \\
\text { age 50 }\end{array}$ \\
\hline 0 & 0 & 0 & 6.41 \\
1 & 0 & 0 & 37.32 \\
0 & 1 & 0 & 9.14 \\
1 & 1 & 0 & 49.13 \\
0 & 0 & 1 & 9.32 \\
0 & 0 & 1 & 49.82 \\
1 & 1 & 1 & 13.2 \\
\hline
\end{tabular}

Note: Based on results for Model 3 in Table 3 . Simulation assumes men are in Daoyi state farm in 1800 .

Having a father who held an official title dramatically increased the chances that a male would acquire a title of his own in the near future. According to the results for model $\mathrm{I}$ in Table 3, men whose fathers held a title were approximately eight $\left(e^{2.09}\right)$ times more likely to acquire a title by the next register than other men. This strong effect persisted in models 2 and 3 even after we controlled for the possession of titles by other kin, thus it is not attributable to the tendency for men whose fathers had titles to be from prominent families where many senior kin held titles. If that were the case, the addition of controls for other senior kin would have diluted the effect for father.

The existence of other senior kin who held titles also improved the chances that a male would obtain one, even if they lived in other households. According to the results for model 3 , each co-resident paternal uncle with a title increase the chances of obtaining one by 44.8 per cent. ${ }^{42}$ Non-co-resident fathers' cousins with titles had an essentially identical effect: each one raised the chances of obtaining a title by 47.5 per cent. The strength of the influence of the characteristics of nonresident kin on mobility outcomes is remarkable given the finding in Campbell and Lee ${ }^{43}$ that being related to someone with a title only increased the chances that a male would marry if the kin holding the title lived in the same household. It appears that a prominent relative living in another household was more useful when acquiring a title than when acquiring a wife.

Being the son of someone with a title, however, was no guarantee of obtaining one. Table 4 presents the chances of obtaining a title by age fifty

42. $100^{*}\left(e^{0.37}-\mathrm{I}\right)=44.8$.

43. Campbell and Lee, "Connections Within and Between Households". 
sui for men from different backgrounds, calculated from simulations based on the results for model 3 in Table 3 . According to these results, slightly more than one-third of the men whose fathers held titles could expect to acquire a title of their own. Even the relatively few men who were fortunate enough to have more than one senior kin with a title were not certain of obtaining one. Only half of the men who had both a father and an uncle with a title would obtain one themselves. The chances were similar for men who had both a father and a father's cousin who held titles. Men appeared to need at least three senior kin with titles before their own probability of obtaining a title reached two-thirds.

Comparison with the few relevant published results suggests that the sons of holders of official titles in rural Liaoning experienced no more downward mobility than the sons of privileged urban residents in North America before the twentieth century. ${ }^{44}$ In other words, elites elsewhere were as successful or more successful than the Liaoning elites at transmitting their status. Thus, analysis of a sample of men in the United States whose records in the I 880 and I 900 censuses were linked, revealed that nearly 60 per cent of men whose fathers held white-collar occupations in I 880 were themselves in white-collar occupations in 1900.45 In Boston during the late nineteenth and early twentieth centuries, between $5 \mathrm{I}$ and $7 \mathrm{I}$ per cent of the sons of men with high white-collar occupations ended up with an occupation in the same stratum as their fathers. ${ }^{46}$ In Hamilton, Canada during the middle of the nineteenth century, 67 per cent of the sons of men involved in clerical or professional work ended up doing such work themselves. ${ }^{47}$ Only in Poughkeepsie was downward mobility for the children elites as high as in rural Liaoning. Only 35 per cent of the sons of men in high white-collar occupations ended up in that stratum themselves. $4^{8}$

The sons of rural Liaoning elites also seem to have been more likely to experience downward mobility than their urban European counterparts. In England during the last half of the nineteenth century, 42.8 of the sons of men in the highest occupational class ended up in that class themselves. ${ }^{49}$ In Frankfurt, Germany, during the middle of the nineteenth century, 77.6 per cent of the sons of merchants were themselves merchants,

\footnotetext{
44. Obviously, the largely urban populations referred to here are not the ideal comparison group for evaluating the rigidity of rural Liaoning society. Comparison with rural populations would be preferable. We are still in the process of locating relevant published results for non-Chinese rural populations, and hope in a future revision of this paper to incorporate such results.

45. Landale and Guest, "Generation, Ethnicity, and Occupational Opportunity", p. 285.

46. Thernstrom, The Other Bostonians, p. 89.

47. Katz, The People of Hamilton, p. 172.

48. Griffen and Griffen, Natives and Newcomers, p. 67.

49. Miles, Social Mobility, p. 23.
} 
Table 5. Family backgrounds of men attaining titles, Liaoning, I789-I909

\begin{tabular}{lccc}
\hline Father has title & $\begin{array}{c}\text { Co-resident uncles } \\
\text { with title }\end{array}$ & $\begin{array}{c}\text { Non-co-resident } \\
\text { fathers' cousins } \\
\text { with titles }\end{array}$ & $\begin{array}{c}\text { Percentage of men } \\
\text { attaining a title } \\
\text { with specified } \\
\text { background }\end{array}$ \\
\hline 0 & 0 & 0 & 62.48 \\
1 & 0 & 0 & 16.99 \\
0 & 1 & 0 & 3.81 \\
1 & 1 & 0 & 8.83 \\
0 & 0 & 1 & 3.07 \\
1 & 0 & 1 & 2.65 \\
1 & 1 & 1 & 0.06 \\
\hline
\end{tabular}

Note: Based on results for Model 3 in Table 3.

and 46.5 per cent of the sons of professionals were professionals. ${ }^{50}$ In Toulouse, France, during the middle of the nineteenth century, nearly two-thirds of grooms of bourgeoise parentage were themselves bourgeoise. ${ }^{\mathrm{I}}$ In Norwich, England, during the sixteenth and seventeenth centuries, between 50.3 and 65.7 per cent of the sons of men in the merchant elites were themselves members of the merchant elite..$^{2}$

At least in rural Liaoning, therefore there is little evidence to support Hymes's claim 53 that the availability of help from distant kin made Chinese society more rigid than the association between fathers' and sons' outcomes would suggest. Indeed, high rates of downward mobility among the children and nephews of titleholders created opportunities for men from undistinguished backgrounds. Table 5 presents distributions of family backgrounds for the men who acquired titles, based on predicted probabilities for actual observations. According to these results, almost two-thirds of the men who acquired titles had no senior kin with a title. Only slightly more than one-sixth were the sons of men with titles. The remaining one-sixth consisted of men who had more than one senior kin with a title.

Compared to elites in North America, therefore, office holders in rural Liaoning were as likely or more likely to be "new blood". In the United States, 28.5 per cent of the young men who were white-collar in I 900 were the sons of men who had been white-collar in I880.54 In Hamilton,

50. Sharlin, "From the Study of Social Mobility", p. 352.

5. Aminzade and Hodson, "Social Mobility", p. 450.

52. Peter S. Bearman and Glenn Deane, "The Structure of Opportunity: Middle-Class Opportunity in England, I 548-1689", American Journal of Sociology, 98 (1992), pp. 30-66.

53. Hymes, Statesmen and Gentlemen, pp. 29-62.

54. Landale and Guest, "Generation, Ethnicity, and Occupational Opportunity", p. 285. 
Table 6. Complementary log-log regression of effects of kin characteristics on title attainment, Liaoning, I789-1909

\begin{tabular}{|c|c|c|}
\hline \multirow[t]{2}{*}{ Variable } & \multicolumn{2}{|c|}{ Model 4} \\
\hline & Coeff. & $\mathrm{P}$ \\
\hline $\begin{array}{l}\text { Dataset (reference: Daoyi) } \\
\text { Gaizhou } \\
\text { Chengnei } \\
\text { Feicheng Yimiancheng } \\
\text { Gaizhou Manhan } \\
\text { Dadianzi } \\
\text { Guosantun } \\
\text { Bakeshu } \\
\text { Daxingtun } \\
\text { Nianma Dahai } \\
\text { Changzhaizi }\end{array}$ & $\begin{array}{r}-0.382 \\
0.174 \\
-0.744 \\
0.711 \\
-0.578 \\
0.193 \\
0.404 \\
-0.354 \\
-0.900 \\
0.383\end{array}$ & $\begin{array}{l}0.20 \\
0.49 \\
0.00 \\
0.00 \\
0.01 \\
0.24 \\
0.04 \\
0.02 \\
0.00 \\
0.03\end{array}$ \\
\hline $\begin{array}{l}\text { Age (reference: } 11-20 \text { sui) } \\
21-30 \text { sui } \\
31-40 \text { sui } \\
41-50 \text { sui } \\
\text { Year-1800 } \\
\text { Post-1860* (year-1860) } \\
\text { Next register } 6 \text { years away }\end{array}$ & $\begin{array}{r}0.371 \\
0.044 \\
-0.176 \\
0.000 \\
-0.019 \\
0.754\end{array}$ & $\begin{array}{l}0.00 \\
0.74 \\
0.30 \\
0.95 \\
0.01 \\
0.00\end{array}$ \\
\hline $\begin{array}{l}\text { Titles } \\
\text { Father has title } \\
\text { \# Co-resident uncles with title } \\
\text { \# Co-resident fathers' cousins with title } \\
\text { \# Non-co-resident fathers' cousins with title } \\
\text { \# Brothers with title } \\
\text { \# Co-resident cousins with title } \\
\text { \# Co-resident second cousins with title } \\
\text { \# Non-co-resident second cousins with title }\end{array}$ & $\begin{array}{l}1.826 \\
0.23 \\
-0.123 \\
0.299 \\
0.771 \\
0.213 \\
-0.137 \\
0.057\end{array}$ & $\begin{array}{l}0.00 \\
0.02 \\
0.34 \\
0.00 \\
0.00 \\
0.03 \\
0.68 \\
0.62\end{array}$ \\
\hline $\begin{array}{l}\text { Other family and housebold characteristics } \\
\text { Eldest brother in sibset } \\
\text { \# Living brothers in sibset } \\
\text { \# Males in the household } \\
\text { Intercept } \\
\mathrm{N}\end{array}$ & $\begin{array}{r}0.464 \\
0.042 \\
0.013 \\
-5.861 \\
78,106\end{array}$ & $\begin{array}{l}0.00 \\
0.39 \\
0.08 \\
0.00\end{array}$ \\
\hline
\end{tabular}

Ontario, 64.5 per cent of the men involved in clerical or professional work were the sons of fathers who held such occupations.55 In Poughkeepsie, New York, 62.8 per cent of the men with high white-collar occupations were the sons of men who had held such occupations. ${ }^{56}$ In Boston,

56. Griffen and Griffen, Natives and Newcomers, p. 67. 
Table 7. Predicted probabilities of attaining a title by age 50 sui according to the characteristics of kin, Liaoning, 1789-1909

\begin{tabular}{lccccc}
\hline $\begin{array}{l}\text { Father } \\
\text { has title }\end{array}$ & $\begin{array}{c}\text { Co-resident } \\
\text { brothers with } \\
\text { title }\end{array}$ & $\begin{array}{c}\text { Co-resident } \\
\text { uncles with } \\
\text { title }\end{array}$ & $\begin{array}{c}\text { Co-resident } \\
\text { cousins with } \\
\text { title }\end{array}$ & $\begin{array}{c}\text { Non-co-resident } \\
\text { fathers' cousins } \\
\text { with title }\end{array}$ & $\begin{array}{c}\text { Percentage of } \\
\text { men attaining } \\
\text { atitle by age } \\
50\end{array}$ \\
\hline 0 & 0 & 0 & 0 & 0 & 4.47 \\
0 & 0 & 0 & 0 & 1 & 5.98 \\
0 & 0 & 0 & 1 & 0 & 5.50 \\
0 & 0 & 0 & 1 & 1 & 7.35 \\
0 & 0 & 1 & 0 & 0 & 5.59 \\
0 & 0 & 1 & 0 & 1 & 7.47 \\
0 & 0 & 1 & 1 & 0 & 6.87 \\
0 & 1 & 0 & 0 & 0 & 12.42 \\
0 & 1 & 0 & 0 & 1 & 11.52 \\
0 & 1 & 0 & 1 & 0 & 11.70 \\
0 & 1 & 1 & 0 & 0 & 24.72 \\
1 & 0 & 0 & 0 & 0 & 31.81 \\
1 & 0 & 0 & 0 & 1 & 29.63 \\
1 & 0 & 0 & 1 & 0 & 30.04 \\
1 & 0 & 1 & 0 & 0 & 45.88 \\
1 & 1 & 0 & 0 & 0 & 0.45 \\
\hline
\end{tabular}

Note: Based on results in Table 6. Simulation assumes that men are in the Daoyi state farm in 1800 .

depending on time period, between one-third and three-quarters of men in high white-collar occupations were the sons of men in such occupations. ${ }^{57}$

Comparison with European populations yields similar conclusions. In Frankfurt, 46.8 per cent of sons who were merchants had fathers who were merchants, and 52.5 per cent of sons who were professionals had fathers who were professionals. ${ }^{58}$ In Toulouse, France, between two-thirds and four-fifths of sons who were bourgeoise were of bourgeoise parentage. ${ }^{99}$ In Norwich, England, between 56.7 and 83 per cent of the sons who were in the merchant elite had fathers in the same category. ${ }^{60}$ In England during the last half of the nineteenth century, 57.I per cent of the men in the highest occupational class were the sons of men in that class. ${ }^{61}$

Holding the characteristics of senior relatives constant, some households nevertheless appear to have been better at securing opportunities for their sons than others. There was pronounced clustering of title attainment

57. Thernstrom, The Other Bostonians, p. 89.

58. Sharlin, "From the Study of Social Mobility", p. 352.

59. Aminzade and Hodson, "Social Mobility", p. 450.

60. Bearman and Deane, "The Structure of Opportunity", p. 30.

6r. Miles, Social Mobility, p. 25. 
Table 8. Attainment of title among brothers according to possession of title by father and number of surviving brothers in sibset, Liaoning 1789-1909

\begin{tabular}{|c|c|c|c|c|c|c|}
\hline \multirow[b]{2}{*}{$\begin{array}{l}\text { \# Surviving } \\
\text { brothers } \\
\text { aged } 41-50 \\
\text { in sibset }\end{array}$} & \multicolumn{3}{|c|}{ Father has no title } & \multicolumn{3}{|c|}{ Father has title } \\
\hline & $\begin{array}{l}\text { Average \# } \\
\text { brothers } \\
\text { in sibset } \\
\text { with title }\end{array}$ & $\begin{array}{c}\% \text { of sibsets } \\
\text { with at least } \\
1 \text { brother } \\
\text { with title }\end{array}$ & $\begin{array}{c}\text { \# of } \\
\text { sibsets }\end{array}$ & $\begin{array}{l}\text { Average \# } \\
\text { brothers } \\
\text { in sibset } \\
\text { with title }\end{array}$ & $\begin{array}{c}\% \text { of sibsets } \\
\text { with at least } \\
1 \text { brother } \\
\text { with title }\end{array}$ & $\begin{array}{c}\# \text { of } \\
\text { sibsets }\end{array}$ \\
\hline 1 & 0.029 & 2.85 & 3,293 & 0.348 & 34.8 & 293 \\
\hline 2 & 0.062 & 5.63 & 870 & 0.616 & 40.6 & 138 \\
\hline 3 & 0.091 & 8.02 & 187 & 0.721 & 46.5 & 43 \\
\hline $4+$ & 0.246 & 18.03 & 61 & 1.333 & 66.7 & 15 \\
\hline Total & 0.041 & 3.83 & 4,411 & 0.487 & 38.4 & 489 \\
\hline
\end{tabular}

among related men of the same generation living in the same household. Table 6 presents results from an analysis that includes as explanatory variables counts of the numbers of brothers, cousins, and second cousins with official titles. Every additional brother with a title more than doubled the chances of obtaining one. Every additional co-resident cousin with a title increased the chances of obtaining one by 24.6 per cent. Kin of the same generation but living elsewhere appear not to have had any effects; thus, this appears to have been largely a household phenomenon.

Clustering effects appear to have been most important for the men who were at higher risk of obtaining a title because of their parentage. According to the predicted probabilities in Table 7, 45 per cent of men who had both a father and a brother with titles would obtain one. In contrast, only 30 per cent of the men who had a father but no brothers with a title would obtain one, a is percentage-point disadvantage. While the proportional effect of a brother with a title was just as strong for men whose fathers had no title, the absolute effect was much weaker, so that having a brother with a title yielded only a 5 percentage-point advantage. Since the effects of clustering were concentrated among the men who were already predisposed to acquire a title by their parentage, a replication of the calculations in Table 5, not shown here, show that the proportion of title holders who have no kin with titles declines only slightly when brothers and cousins are accounted for.

One implication of this clustering was that for a man with a title, having many surviving sons was not necessarily an efficient strategy for ensuring that at least one son acquired a title. Additional sons had a much smaller effect on the chances that at least one would obtain a title than would be the case in the absence of clustering. Table 8 presents the results of an examination of title attainment among sets composed of brothers surviving at least to age forty. It presents the percentages of sets where at least one 
brother obtains a title, distinguishing by size of the set and whether or not the father held a title. According to these results, if a man with a title had one son who survived into his early forties, there was a 34.8 per cent chance that he would acquire a title. If a man with a title had two surviving sons, however, there was only a 40.6 per cent chance that at least one would have a title. These numbers are very different from the ones expected if the chances of attaining a title were independent of sibset size and not subject to clustering. If that were the case, 38.4 per cent of only sons would acquire titles, and 62.I per cent of brother pairs would include at least one brother with a title. ${ }^{62}$

\section{CONCLUSION}

We have demonstrated that longitudinal, nominative data from population registers has considerable potential to open up a new avenue of inquiry in the analysis of social mobility. We expanded the focus from the father-son dyad to the extended family, including nonresidential kin. By linking individuals to their distant relatives, including those living in other households, and using the measured characteristics of those relatives as explanatory variables, we carried out an analysis of social mobility that properly accounted for the potentially important role of kin other than parents and siblings. We were able to translate influential claims about the role of kinship networks in social mobility in historical China into testable hypotheses, and evaluate them.

While our specific interest was in accounting for the potential importance of distant kin in mobility outcomes in a Chinese setting, these results should be of general interest because of the novelty of our approach. To our knowledge, comparable studies that consider the potential effects on mobility outcomes of senior kin other than the father and grandfather are extremely rare, not just for historical societies, but for contemporary societies as well. We have demonstrated here that even when the characteristics of father and grandfather are controlled for, effects are apparent for other senior kin. As similarly detailed and voluminous household register data for other historical societies become available, we look forward to comparison with results from the replication of these calculations. Such comparison would help assess whether the effects of senior kin reflect the distinct characteristics of kinship networks in historical China, or are typical for historical societies. In the absence of comparable results from elsewhere, we cannot answer this question, only offer these results as a baseline for comparison for future studies.

Our most important substantive finding, of course, is that kin other than the father influenced mobility outcomes in Liaoning. Having an uncle or a

62. $\mathrm{I}-(\mathrm{I}-0.384)^{2}=0.62 \mathrm{I}$. 
father's cousin with a title raised the chances of obtaining one. Inheritance of status, in other words, could be indirect. Even more importantly, we found that characteristics of kin living in other households mattered for the acquisition of a title, even though in a previous analysis we found no evidence that they influenced key demographic outcomes such as the chances of ever marrying. ${ }^{6}{ }^{3}$ Prominent kin living in other households may have been a useful form of social capital when it came to acquiring a title, but not when it came to acquiring a spouse. Kinship networks beyond the household, in other words, may have been more important as a source of social capital than as a source of economic capital.

Rural Liaoning nevertheless appears to have been as open as many other historical populations for which it has been possible to analyze social mobility, if not more so. The sons and other junior kin of title holders were as likely or more likely to experience downward mobility than the sons of elites in selected North America and European populations. Even though having a title increased the chances that a son or other junior kin would acquire one, in other words, it was by no means a guarantee. Conversely, even when we allowed for the possibility of indirect inheritance, for example from men to their nephews, the proportion of the elites who were "new" was as high as in the European and North American populations to which comparison were made. At least in this part of China, the emphasis on merit in the allocation of titles by the state appears to have overridden tendencies towards nepotism and particularism. ${ }^{64}$

The claim that weak associations between the outcomes of fathers and sons exaggerate the openness of historical Chinese society by failing to account for the tendency of networks of kin to monopolize opportunities $^{65}$ appears not to be correct. While some families were especially successful at transmitting status from one generation to the next, the effects of characteristics of senior kin on outcomes were too weak to guarantee success for the junior kin in prominent families. Though Liaoning was but one part of China, and the population studied here was a distinct subgroup within Liaoning, the findings here are likely to be relevant to other parts of the country, since, as noted in Lee and Campbell ${ }^{66}$ and $\mathrm{Ho},{ }^{67}$ the ideology of advancement according to individual merit was a long-standing and pervasive feature of Chinese society.

63. Campbell and Lee, "Connections Within and Between Households".

64. Lang, Chinese Family, pp. I8I-192.

65. Hymes, Statesmen and Gentlemen, pp. 29-62.

66. Lee and Campbell, Fate and Fortune, pp. 10-15, I96-214.

67. Ho, The Ladder of Success, pp. I- 52. 